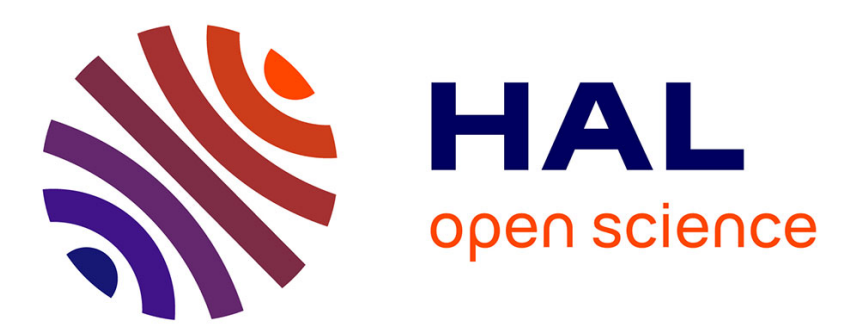

\title{
Physiological responses to temperature in Merizodus soledadinus (Col., Carabidae), a subpolar carabid beetle invading sub-Antarctic islands
}

\author{
M. Laparie, D Renault
}

\section{- To cite this version:}

M. Laparie, D Renault. Physiological responses to temperature in Merizodus soledadinus (Col., Carabidae), a subpolar carabid beetle invading sub-Antarctic islands. Polar Biology, 2016, 39 (1), pp.35-45. 10.1007/s00300-014-1600-0 . hal-01255879

HAL Id: hal-01255879

https://hal-univ-rennes1.archives-ouvertes.fr/hal-01255879

Submitted on 14 Jan 2016

HAL is a multi-disciplinary open access archive for the deposit and dissemination of scientific research documents, whether they are published or not. The documents may come from teaching and research institutions in France or abroad, or from public or private research centers.
L'archive ouverte pluridisciplinaire HAL, est destinée au dépôt et à la diffusion de documents scientifiques de niveau recherche, publiés ou non, émanant des établissements d'enseignement et de recherche français ou étrangers, des laboratoires publics ou privés. 


\title{
Physiological responses to temperature in Merizodus soledadinus (Col., Carabidae), a subpolar carabid beetle invading sub-Antarctic islands
}

\author{
Laparie M. ${ }^{1}$ and Renault D. ${ }^{2}$ \\ ${ }^{1}$ INRA, UR0633, Forest Zoology Research Unit (URZF), 2163 Avenue de la pomme de pin, CS 40001 \\ Ardon, F-45075 Orléans, France \\ ${ }^{2}$ Université de Rennes 1, UMR CNRS 6553 Ecobio, 263 Avenue du Gal Leclerc, CS 74205, 35042 Rennes \\ Cedex, France
}

Correspondence: Mathieu Laparie, E-mail: mathieu.laparie@orleans.inra.fr, Phone: +33238417898

\begin{abstract}
Recent human activities and rising air temperature have increased the vulnerability of sub-Antarctic islands to alien species. At the Kerguelen Islands, the predaceous ground beetle Merizodus soledadinus is the only invasive insect originating from the southern cold temperate area (native from Patagonia, Tierra del Fuego and Falkland Islands). This austral origin raises the question of the limits of its physiological tolerance and capability to withstand (i) global change and (ii) warmer climates of archipelagos where its accidental transportation could be facilitated from the Kerguelen Islands (namely Amsterdam \& Saint Paul). Using GCMS metabolomics, we compared metabotypes of adults exposed to different temperatures $(0,4,8,12,16$, $20^{\circ} \mathrm{C}$ ). All individuals survived after two weeks regardless of the temperature they were exposed to. The physiological changes observed were consistent with increased metabolic rate at increased temperatures, without extreme metabotypes that are characteristic of acute stress. First cues of sub-lethal stress were observed after prolonged exposure to $20^{\circ} \mathrm{C}$, a warm regime unrealistic for such duration in sub-Antarctic Islands. Overall, $M$. soledadinus' thermal tolerance exceeded temperatures currently experienced in nature, suggesting that climate warming may boost its invasion by eliciting its activity and broadening habitat suitability in both invaded and still pristine islands. This thermal tolerance may allow survival aboard ships and development in sub-Antarctic islands with conditions warmer than the Kerguelen Islands, such as Amsterdam \& St Paul. Stringent biosecurity measures are thus needed to prevent transfer from Kerguelen to these islands. The native range of this predaceous beetle limited to the Falkland Islands and southernmost South America may be partly constrained by factors other than temperature, such as desiccation, predation or competition.
\end{abstract}

\section{Keywords}

Biological invasion, Insect, Kerguelen Islands, Metabolomics, Metabolic rate, Plasticity, Thermal stress, Thermal tolerance 


\section{Introduction}

Globalization and increasing intensity of human activities (i.e., commerce routes connecting distant areas, human flows, climate change) have lowered geographic and climatic barriers to alien introductions in the last decades, resulting in a dramatic increase of their number worldwide (Cassey et al. 2005; Hulme et al. 2008). Resulting invasions often have profound detrimental ecological consequences (Vitousek et al. 1997; Simberloff 2011), and managing the risks requires a better understanding of what hinders aliens' success and keeps them from turning into invaders. Sub-Antarctic islands are no exception to biological invasions, even though they have long been protected from aliens due to their late discovery, geographic isolation, climatic barrier, and absence of permanent inhabitants (Chown et al. 1998; Frenot et al. 2001; 2005). However, even though human activities still remain limited, these islands are becoming especially vulnerable as these barriers to invasions tend to be removed (Lebouvier et al. 2011). To date, six insect species are invasive in the Kerguelen Islands, five of them being cosmopolitan species with widespread worldwide range or temperate origin (Frenot et al. 2005). So far, only the ground beetle Merizodus soledadinus Guérin-Méneville (Col., Carabidae) originates from a native area restricted to about the same latitude as the Kerguelen Islands, in the cold southern temperate area (Patagonia, Tierra del Fuego and Falkland Islands; Jeannel 1940; Johns 1974; Chevrier 1996; Roig-Junent and Dominguez 2001; Convey et al. 2011). In the recipient environment, this flightless predaceous insect has encountered biotic (prey communities and their distribution) and abiotic conditions (cooler temperatures) that differ from its native area. Yet, its spread and dominance in most littoral habitats and in some inland areas of the eastern peninsula of the Kerguelen Islands clearly show its success as an invasive species (Lebouvier et al. 2011).

The activity of physiological systems of ectotherms is strongly dependent on external temperature, and their degree of plasticity sets the performance range of functions such as locomotion, reproduction, or even growth and survival (Huey and Kingsolver 1989; Hazell and Bale 2011), all being important to invasiveness. Sub-lethal deviations from an optimal range can constrain physiological mechanisms because of enzymatic thermal kinetics (see Huey and Kingsolver 1989), or make metabolic rate and net energy production drop towards a point where energy requirements for biological functions cannot be fulfilled anymore. Both the thermal sensitivity and the sequence at which functions are switched off vary among organisms, and investigating thermal physiology of $M$. soledadinus is thus a key task for the better understanding of its current and future invasive success. Lalouette et al. (2012) reported increasing aerobic metabolism from 0 to $16{ }^{\circ} \mathrm{C}$ in this species, and showed that the lower sub-lethal thermal threshold of activity (indicated by chill coma; see Hazell and Bale 2011) can be reached during winters on Kerguelen Islands, as it ranges from 5.5 to $3{ }^{\circ} \mathrm{C}$ depending on acclimation procedure. Interestingly, long-term monitoring showed that the invasive range of $M$. soledadinus exploded in the 1990s at the Kerguelen Islands (Lalouette et al. 2012), about 80 years after introduction but only 10 to 15 years after a steep increase in mean air temperature (Lebouvier et al. 2011). 
Altogether, these observations support the idea that the high-paced climate change in the polar region is reducing potential barriers to aliens in the Kerguelen Islands, facilitating access to previously unsuitable habitats, activity, demographic growth, and consequently invasion rate.

While it has been hypothesized that sensitivity to climate warming decreases at increased latitudes (Deutsch et al. 2008), the restricted subpolar origin of $M$. soledadinus suggests a narrower performance range than cosmopolitan and temperate insects currently invading the Kerguelen Islands. As ongoing warming may relax lower thermal limits of its biological functions during winter, this species may more readily get close to its higher thermal limits during summer than temperate species. Therein, the questions are raised of how broad is the thermal tolerance of $M$. soledadinus, and to what extent its invasion may benefit from warming. The thermal sensitivity of its metabolism may be crucial in predicting (i) this species' responses to long-term climate change, and (ii) potential success in warmer islands to which accidental transportation from the Kerguelen Islands may be assisted by ships moving in the region (military, scientific or fisheries) - namely Amsterdam \& St Paul archipelago. Lalouette et al. (2012) have reported that M. soledadinus has little thermal plasticity, but enough scope to deal with the current climate of the Kerguelen Islands. Untangling the physiological mechanisms underlying its responses to thermal variations (and the magnitude of the responses) is now critical in clarifying the beneficial effects of warming, yet it remains unsolved so far.

In the present study, we aim to fill this knowledge gap by examining physiological responses of M. soledadinus to thermal variations using modern metabolomics (GC-MS), assuming signs of increased activity at moderately warm temperatures up to a threshold resulting in mortality or physiological damages. Changes in environmental variables are associated with metabolic reconfiguration in insects (Overgaard et al. 2007; Laparie et al. 2012; Mamai et al. 2014), and the accumulation of specific metabolites thus represents a good marker of physiological thermal thresholds in ectothermic species (Colinet et al. 2012). We hypothesized contrasted metabolic phenotypes depending on thermal acclimation, based on (i) increased amounts of amino acids and polyamines at stressful temperatures resulting from the degradation of misfolded proteins, (ii) accumulation of compatible solutes at low temperatures, and (iii) decreased amounts of circulating sugars and tricarboxylic intermediates with increasing temperatures due to higher use and turnover (elicited activity). The experiment was performed on adults exposed to a range of temperatures from 0 to $20^{\circ} \mathrm{C}$, with or without food because energy shortage may alter the extent of physiological stress observed. The range of temperature investigated was intentionally broader than the range that can actually be encountered in nature for the durations we used (two weeks), so that limits of M. soledadinus' thermal plasticity could be pinpointed by tracking possible physiological damages. The findings on M. soledadinus' thermal responses are ultimately discussed in the light of risks of invasive bridgehead effect (Lombaert et al. 2010) from the Kerguelen Islands to other subAntarctic islands, as survival to thermal conditions aboard ships may trigger the success or failure of accidental transfers of this invasive beetle. 


\section{Material and methods}

\subsection{Sample collection and experimental conditions}

Adult Merizodus soledadinus were hand-collected in December 2010 under stones at Port-aux-Français, Kerguelen Islands ( $49^{\circ} 21^{\prime} \mathrm{S}, 70^{\circ} 13^{\prime} \mathrm{E}$ ). Sets of 10 individuals were directly placed onto paper discs in Petri dishes $(\varnothing 10 \mathrm{~cm})$ and supplied with water in microtubes capped with cotton. The Petri dishes were immediately placed for two weeks in climatic chambers (Panasonic MIR 154) at either 0, 4, 8, 12, 16 or 20 ${ }^{\circ} \mathrm{C}\left( \pm 0.5^{\circ} \mathrm{C}\right)$. A total of twenty Petri dishes were exposed to each temperature.

Enchytraeid worms (that adult M. soledadinus can eat in natura; Laparie et al. 2012a) were supplied ad libitum every three days in ten Petri dishes, except for the last three days of exposure to allow the purge of the digestive tractus before metabolic measurements. Insects in the ten remaining Petri dishes were food-deprived for the whole experiment. Microtubes with water and paper discs were renewed every three days in all Petri dishes.

\subsection{Sample preparation}

All samples consisted of pools of three living individuals randomly picked up from replicates of the Petri dishes exposed to the same experimental condition for two weeks (same temperature and same trophic condition). Microtubes were pre-filled with $1000 \mu \mathrm{L}$ of $70 \%$ ethanol, then weighed, and sets of three randomly selected insects were directly killed when plunged in ethanol in these microtubes. The microtubes were weighed again to deduce the fresh mass of each sample. Two microtubes were discarded because of aberrant (almost null) fresh mass. Eight samples were prepared for each of the 12 experimental conditions (six temperatures, two trophic conditions), with the exception of the two aforementioned outliers, resulting in a total of 94 samples (i.e., 282 individuals). All samples were stored at $-20{ }^{\circ} \mathrm{C}$ prior to metabolic assays.

\subsection{Metabolite Assays}

- Separation and derivatization

Gas Chromatography/Mass Spectrometry (GC-MS) was used to measure the circulating metabolites from the whole insect bodies in each sample. The samples in ethanol were vacuum-dried (Speed Vac Concentrator, MiVac, Genevac Ltd., Ipswich, England), and we used the experimental procedure described in Laparie et al. (2012b) with the following minor modifications. The metabolites were homogenized in $1000 \mu \mathrm{L}$ of methanol-chloroform-water (2:1:2, M:C:W) solution and $300 \mu \mathrm{L}$ aliquots of the upper aqueous phase, which contained polar metabolites, were transferred to microtubes and vacuum-dried. The polar phase aliquots were resuspended in $30 \mu \mathrm{L}$ methoxyaminehydrochloride (Sigma-Aldrich, St. Louis, MO, USA) in pyridine at $20 \mathrm{mg} \cdot \mathrm{mL}^{-1}$ and, following incubation at $40^{\circ} \mathrm{C}$ for $90 \mathrm{~min}, 30 \mu \mathrm{l}$ of N-methyl-N-(trimethylsilyl) trifluoroacetamide (MSTFA; Sigma, \#394866) was added. The derivatization was conducted at $40{ }^{\circ} \mathrm{C}$ for 45 min under agitation. 
- Metabolite analysis

The GC-MS system was comprised of a CTC CombiPal autosampler (GERSTEL GmbH \& Co.KG, Mülheim an der Ruhr, Germany), a Trace GC Ultra chromatograph, and a Trace DSQII quadrupole mass spectrometer (Thermo Fischer Scientific Inc, Waltham, MA, USA) (see Khodayari et al. 2013 for a full description and picture of the equipment). We used the same GC-MS settings as those described in Laparie et al. (2012b).

All samples were run under the SIM mode (electron energy: $-70 \mathrm{eV}$ ), which ensures increased sensitivity relative to full scan analysis by focusing on target metabolites (Waller et al. 2007). Therefore, we only screened for the 60 pure reference compounds included in our spectral database. GC-MS peaks were accurately annotated using both mass spectra (two specific ions), and retention index specific to each compound. A quality control containing the 60 pure compounds at $200 \mu \mathrm{M}$ was run every 15 samples to verify instrument performance, set intervention limits, and basic instrument validation for metabolite profiling (Fiehn et al. 2008). Randomized sample sequences were established for sample injection, and each sequence was initiated with a quality control. In addition, our CTC CombiPal autosampler (GERSTEL GmbH \& Co.KG, Mülheim an der Ruhr, Germany) enabled online derivatization and standardization of the preparation process. Calibration curve samples for 60 pure reference compounds at $10,20,50,100,200$, 500, 700, 1000 and $1500 \mu \mathrm{M}$ concentrations were run. Chromatograms were deconvoluted using XCalibur 2.0.7, and metabolite levels were quantified using the quadratic calibration curves for each reference compound and concentration. Arabinose was used as the internal standard.

\subsection{Statistical analyses}

Effects of acclimation, trophic status and their interaction on the different metabolic families (i.e., total amounts of free amino acids (FAA), intermediate acidic metabolites (IAM), sugars, polyols and amines) were studied using two-way Anovas. Amounts of individual circulating molecules were then considered to investigate metabolic differences among the groups of individuals. Given the number of metabolites measured, we used multivariate procedures after removal of strongly correlated metabolites. First, the effects of acclimation, trophic status and their interaction on metabolic profiles were studied using a Manova. Second, metabolic differences among thermal conditions were detailed separately in fed and food-deprived individuals using two Linear Discriminant Analyses (LDA). Statistical significance of both discriminations was confirmed using Monte-Carlo permutation tests at $\alpha$ threshold $=0.001\left(10^{\prime} 000\right.$ permutations). Multivariate homogeneity of class variances was checked using Within-Group Analyses. Results of individual Anovas are also reported in electronic supplementary materials to provide univariate information on the variations of each molecule used to differentiate groups. The false discovery rate resulting from multiple comparisons was corrected using the Two-Stage Benjamini-Hochberg algorithm ( $\alpha$ threshold $=0.05$ ) on $p$-values for acclimation, trophic status, and their interaction. 
Statistical analyses were performed on log-transformed data to improve adequacy of models' residuals to normal distribution, which was checked using QQ plots and Shapiro-Wilk tests for multivariate normality. All analyses were conducted with $R^{\mathrm{TM}}$ 2.11.0 statistical software (R Development Core Team 2008).

\section{Results}

\subsection{Survival to experimental conditions and accuracy of metabolic measurements}

All insects survived after two weeks of exposure to the six thermal regimes, in both trophic conditions.

Among the 60 compounds included in our library, 37 were detected in the samples, including 11 FAA, 8 polyols, 6 IAM, 6 sugars, 4 amines and 2 diverse metabolites (see detail in ESM1). Compounds beyond quantification limits $(<10 \mu \mathrm{M})$ or insufficiently reliable due to a signal/noise ratio lower than 10 were discarded to ensure accuracy of the data, resulting in 27 molecules conserved for further analyses.

\subsection{Total amounts by molecular class}

Before investigating the variations of individual compounds among the 12 experimental treatments, we compared the variations of the total amounts by metabolic family, namely FAA, IAM, sugars, polyols and amines (Fig. 1; Table 2). The total amount of the diverse compounds measured was not analyzed because it does not correspond to a family, and only gluconolactone and glycerate fell into this group; concentration in gluconolactone being about 200 times higher (ESM2), the results would have provided the same information as the test on this individual molecule in ESM3. Total concentrations in FAA and sugars significantly decreased when the acclimation temperature increased, regardless of the trophic status. Overall, concentrations tended to be the highest in individuals exposed to $0{ }^{\circ} \mathrm{C}$, and significantly dropped after exposure to any of the warmer temperatures. A similar trend appeared in food-deprived individuals for IAMs and polyols despite non-significance of the variations in total concentrations (however, several individual IAM and polyols varied significantly among acclimation treatments; see ESM3). Variations of the total concentration in amines mainly resulted from the trophic status of individuals exposed to $20^{\circ} \mathrm{C}$ : the total concentration was on average higher in fed individuals, up to a two-fold difference in individuals acclimated to $20^{\circ} \mathrm{C}$. 
Table 1 Results of the five two-way Anovas computed on mean total concentration by metabolic family. All numeric data are rounded to one decimal digit

\begin{tabular}{|c|c|c|c|c|c|}
\hline Response variable & Effect & $F_{\mathrm{df}}$ & SS & MS & $p$ \\
\hline \multirow[t]{3}{*}{ Total free amino acids } & Acclimation & $18.0_{5}$ & 8.0 & 1.6 & $* * *$ \\
\hline & Trophic status & $0.2_{1}$ & 0.0 & 0.0 & n.s. \\
\hline & Acclimation:Trophic status & $1.4_{5}$ & 0.6 & 0.1 & n. s. \\
\hline \multirow[t]{3}{*}{ Total intermediate acidic metabolites } & Acclimation & $2.2_{5}$ & 2.0 & 0.4 & n. s. * \\
\hline & Trophic status & $0.7_{1}$ & 0.1 & 0.1 & n.s. \\
\hline & Acclimation:Trophic status & $0.6_{5}$ & 0.7 & 0.1 & n. s. \\
\hline \multirow[t]{3}{*}{ Total sugars } & Acclimation & $8.9_{5}$ & 6.2 & 1.2 & $* * *$ \\
\hline & Trophic status & $1.3_{1}$ & 0.2 & 0.2 & n.s. \\
\hline & Acclimation:Trophic status & $1.4_{5}$ & 0.9 & 0.2 & n. s. \\
\hline \multirow[t]{3}{*}{ Total polyols } & Acclimation & $1.7_{5}$ & 0.8 & 0.2 & n. s. \\
\hline & Trophic status & $0.0_{1}$ & 0.0 & 0.0 & n. s. \\
\hline & Acclimation:Trophic status & $1.4_{5}$ & 0.7 & 0.1 & n. s. \\
\hline \multirow[t]{3}{*}{ Total amines } & Acclimation & $4.9_{5}$ & 4.0 & 0.8 & $* * *$ \\
\hline & Trophic status & $9.6_{1}$ & 1.6 & 1.6 & $* *$ \\
\hline & Acclimation:Trophic status & $1.8_{5}$ & 1.4 & 0.3 & n. s. \\
\hline
\end{tabular}

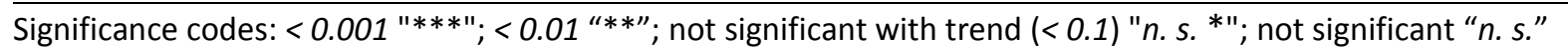
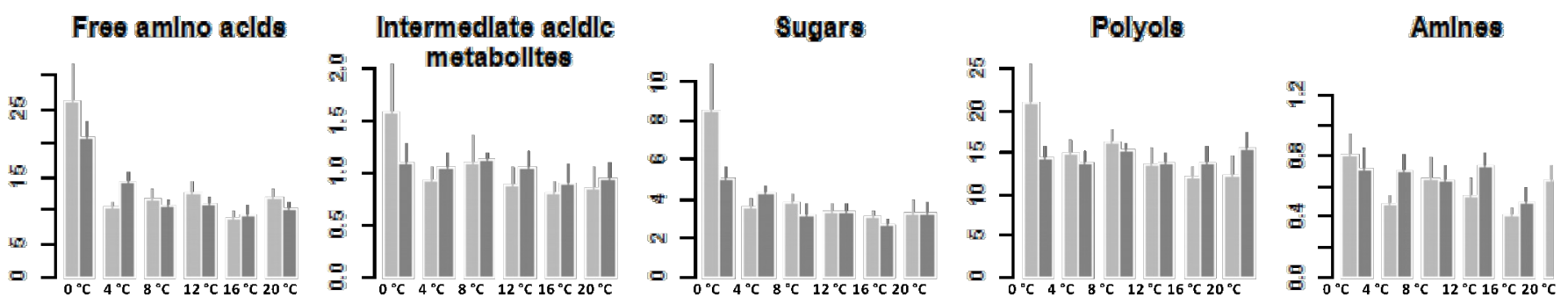

Fig. 1 Total concentration (nmol.mg ${ }^{-1}$ of dry mass) by molecular class, averaged from adults of M. soledadinus acclimated to either $0,4,8,12,16$ or $20^{\circ} \mathrm{C}$ for two weeks. Light grey: food-deprived individuals; dark grey: fed individuals. Error bars: standard error. See ESM1 for the list of molecules measured in each class

\subsection{Changes in the metabolic profiles over the thermal gradient}

To avoid overestimation of differences among experimental treatments and redundancy in the multivariate analyses based on individual metabolites, molecules exceeding a $90 \%$ correlation with others were dropped, resulting in 22 molecules considered for further statistical procedures. The choice of the correlated molecules to retain or discard was based on two criteria: (i) the number of pairwise correlations it was involved in (discarding molecules being the most often correlated allowed keeping more variables and thus more information in the dataset); and (ii) the available literature and overall knowledge of the biological role of these molecules. The metabolic phenotypes (metabotypes) of the ground beetles were significantly altered by acclimation temperature, trophic status, and their interaction (Table 2). 
All 22 compounds varied significantly among acclimation temperatures: five metabolites varied significantly between fed and food-deprived individuals (alanine, cadaverine, fumarate, leucine and maltose; ESM3), and five varied significantly among acclimation temperatures depending on the trophic status of individuals (alanine, erythritol, maltose, trehalose and valine; see Acclimation:Status interaction in ESM3).

Table 2 Results of the Manova computed on the 22 compounds considered for statistical analyses, testing variations upon Acclimation (0, 4, 8, 12, 16 and $20^{\circ} \mathrm{C}$ ), Status (fed vs. food-deprived individuals), and their interaction. All numeric data are rounded to one decimal digit

\begin{tabular}{llll}
\hline Effect & $F_{\mathrm{df}}$ & Pillai & $p$ \\
\hline Acclimation & $6.2_{5}$ & 3.4 & $* * *$ \\
Trophic status & $16.6_{1}$ & 0.9 & $* * *$ \\
Acclimation:Trophic status & $2.4_{5}$ & 2.3 & $* * *$ \\
\hline
\end{tabular}

Significance code: $<0.001^{1 * * * *}$

Linear Discriminant Analyses (LDAs) were used to draw the multivariate metabolic differences from acclimation regimes in fed (Fig. 2) and food-deprived individuals (Fig. 3). In fed individuals, the between-class inertia along the first axis was 18.25 times higher than the within-class inertia. This axis depicted the gradual differences from cold-acclimated individuals to warm-acclimated individuals. Of note, insects acclimated to $0{ }^{\circ} \mathrm{C}$ slightly fell apart from the general trend on LD1, as they projected between those acclimated to $4{ }^{\circ} \mathrm{C}$ and those acclimated to $8{ }^{\circ} \mathrm{C}$. According to the correlations circle, the warmer the acclimation temperature, the lower the concentrations in fumarate, gluconolactone, trehalose, inositol, and FAA such as leucine, glycine, ornithine and alanine (cited in order of decreasing contribution). The LD1 axis also corresponded to increased concentrations in erythritol and cadaverine from cold- to warmacclimated individuals, being especially high in individuals acclimated to $20^{\circ} \mathrm{C}$ (see also ESM2). The between-class inertia was 8.79 times higher than the within-class inertia along LD2. This axis mainly separated individuals acclimated to $0{ }^{\circ} \mathrm{C}$ from other acclimation groups, because of higher concentrations of valine, inositol, succinate, ribose and glucose, and lower concentrations of maltose, cadaverine and citrate.
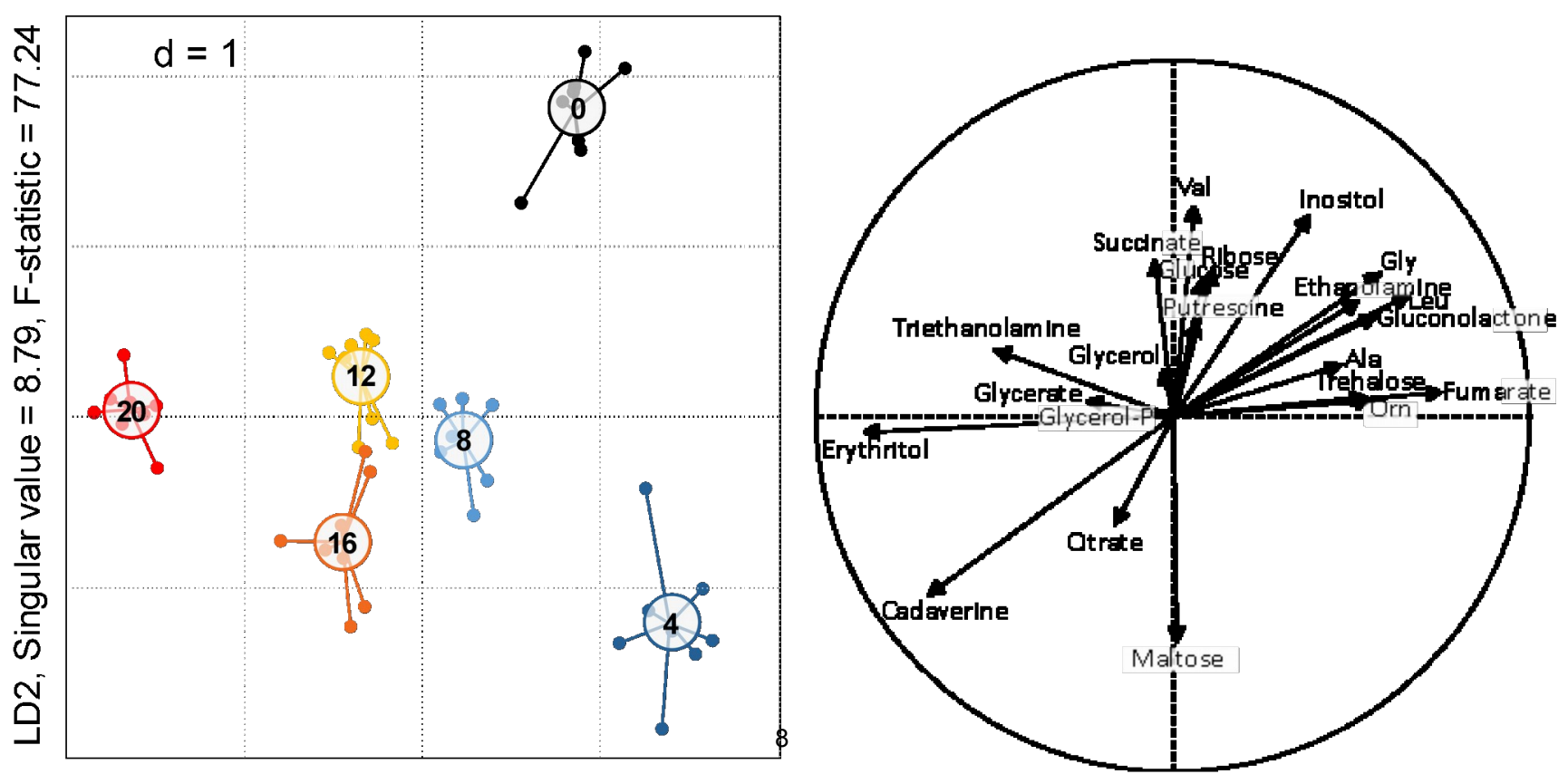

LD1, Singular value $=18.25$, F-statistic $=333.04$ 
Fig. 2 Projection of samples of fed individuals onto the first LDA discriminant plane. Grouping factor considered: acclimation treatment ( 6 classes). The lines link the samples to the centroid of their group; some sample points may be hidden by group labels when close to the centroid. Black: $0{ }^{\circ} \mathrm{C}$; blue $4{ }^{\circ} \mathrm{C}$; light blue: $8{ }^{\circ} \mathrm{C}$; yellow: $12{ }^{\circ} \mathrm{C}$; orange: 16 ${ }^{\circ} \mathrm{C}$; red: $20^{\circ} \mathrm{C}$. The correlations circle depicts the normed relation (from -1 to 1 ) between each compound and the linear discriminant axes. The singular values are the ratio of between-class and within-class inertias.
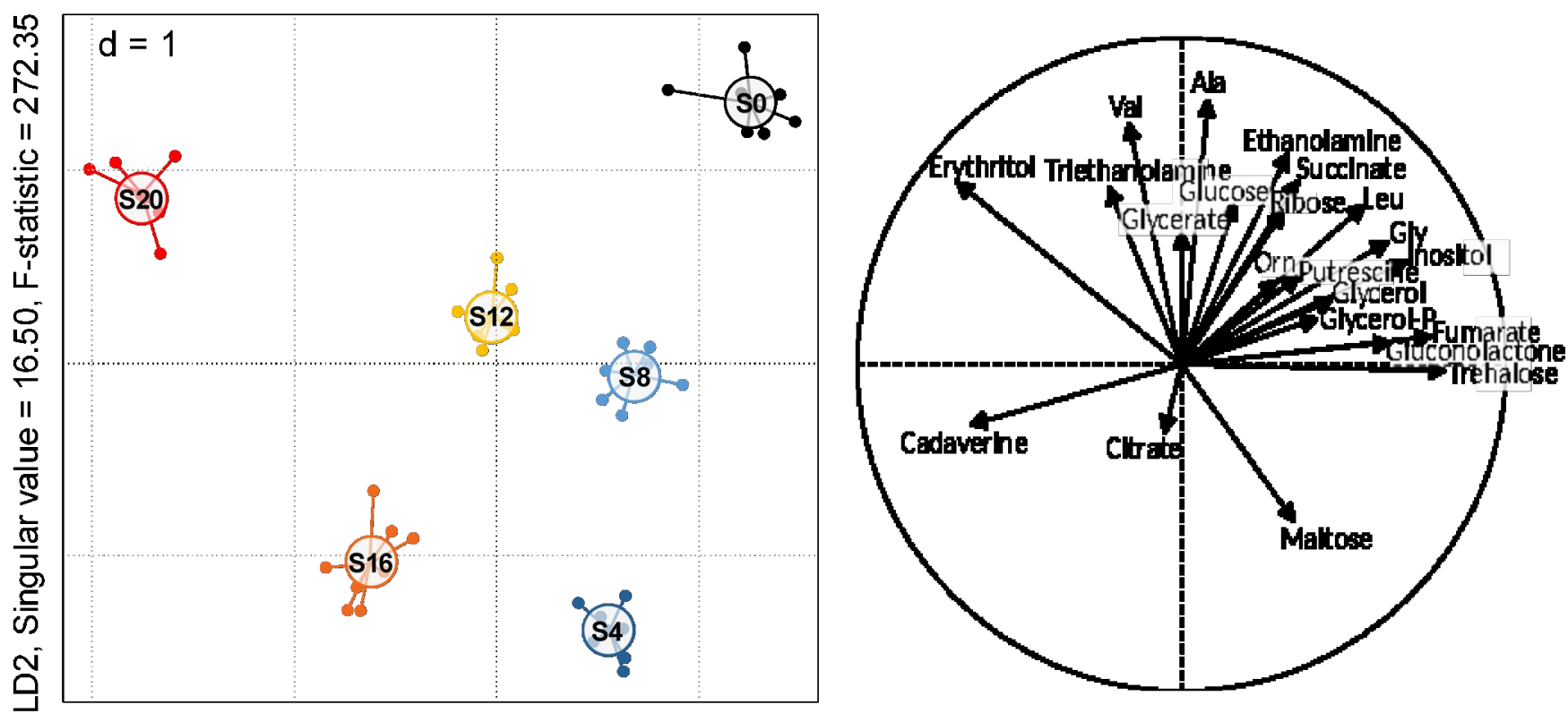

LD1, Singular value $=19.87$, F-statistic $=394.66$

Fig. 3 Projection of samples of food-deprived individuals onto the first LDA discriminant plane. Grouping factor considered: acclimation treatment ( 6 classes). The lines link the samples to the centroid of their group; some sample points may be hidden by group labels when close to the centroid. Black: $0{ }^{\circ} \mathrm{C}$; blue $4{ }^{\circ} \mathrm{C}$; light blue: $8{ }^{\circ} \mathrm{C}$; yellow: $12{ }^{\circ} \mathrm{C}$; orange: $16^{\circ} \mathrm{C}$; red: $20^{\circ} \mathrm{C}$. The correlations circle depicts the normed relation (from -1 to 1 ) between each compound and the linear discriminant axes. The singular values are the ratio of between-class and within-class inertias

In food-deprived individuals (Fig. 3), the between-class inertia along the first axis was 19.87 times higher than the within-class inertia. As in fed individuals, LD1 mainly sorted groups in order of acclimation temperature. Overall, warmer acclimation temperatures resulted in lower concentrations in trehalose, fumarate, gluconolactone, inositol, glycine and leucine. By contrast, erythritol and cadaverine concentrations increased with temperatures, with manifold accumulation of erythritol in individuals exposed to $20^{\circ} \mathrm{C}$. Finally, between-class inertia was 16.50 times higher than within-class inertia along LD2, notably depicting comparatively higher concentrations in alanine and valine in individuals exposed to 0 and $20{ }^{\circ} \mathrm{C}$. The $20^{\circ} \mathrm{C}$ group was characterized by a clear-cut contrasting metabotype with low concentration in maltose, high concentration in valine, and especially high concentration in erythritol, consistently with previous results in fed individuals (see also ESM2). The $0{ }^{\circ} \mathrm{C}$ group showed high concentrations in most sugars, IAM, and FAA. The 4 and $16{ }^{\circ} \mathrm{C}$ groups fell in the lower part of LD2 axis because of comparatively low concentrations in alanine and valine, but high concentrations in maltose. Finally, the 8 and $12^{\circ} \mathrm{C}$ groups were intermediate in the discriminant space and exhibited average concentrations for the most discriminant compounds. Of note, cadaverine concentration was not as high as in fed individuals exposed to $20{ }^{\circ} \mathrm{C}$. Its concentration remained low across treatments, but consistently increased with temperature (see ESM2). 
Overall, several molecules showed rather linear variations across the thermal range, such as gluconolactone, threhalose and fumarate, while other compounds primarily varied in extreme groups only, such as cadaverine, erythritol and ribose (ESM2).

\section{Discussion}

\subsection{Thermal tolerance appears broad enough to withstand warming at the Kerguelen Islands}

Predicting the effects of climate change on species' range has drawn a lot of attention over the past years. However, understanding physiological capacities of species - a critical step for forecasting their responses to climate change - has been underappreciated until recently (Chown et al. 2010). Likewise, little is known about the thermal physiology of $M$. soledadinus and how associated plasticity may assist its invasive success, despite the major threat it represents to endemic invertebrates at the Kerguelen Islands. The thermal plasticity of this predaceous beetle is a prime parameter of its capability to respond to the rapid climate change being recorded in the region (Chown and Smith 1993; Lebouvier et al. 2011), and/or to succeed in other sub-Antarctic archipelagos if accidentally transported. Previous work on survival and respiration of $M$. soledadinus has suggested comparatively limited thermal plasticity to varying temperatures (Lalouette et al. 2012). Meanwhile, all individuals survived the thermal experiments we used, even after two weeks of constant exposure to $20{ }^{\circ} \mathrm{C}$ that we expected as being more stressing (i.e., prolonged exposure to a temperature 10 to $12{ }^{\circ} \mathrm{C}$ warmer than the summer monthly means in the native and invaded areas). Together with the findings from Lalouette et al. (2012), our data suggest that adult $M$. soledadinus can withstand ongoing warming at the Kerguelen Islands, and may even benefit from it. The present work aims at further delineating the thermal tolerance of this invader by investigating plasticity from the lower phenotypic scale, i.e., the physiological scale.

\subsection{The metabolic components that suggest limits of thermal tolerance}

Consistent with our hypotheses, we observed temperature-specific metabolic phenotypes. However, we observed limited physiological signs of thermal stress over the gradient used, and only in individuals exposed to the warmest regime of $20^{\circ} \mathrm{C}$. A typical consequence of thermal stress in insects is protein breakdown, which suggests progressive failure of the mechanisms dedicated to protecting protein integrity (Colinet et al. 2012). Concentrations in two essential amino acids (valine and the highly correlated isoleucine) increased in food-deprived individuals exposed at $20^{\circ} \mathrm{C}$, which tends to indicate the occurrence of this phenomenon. However, we observed no consistent increase of the total concentration of FAA nor individual FAA at $20^{\circ} \mathrm{C}$, as it would be expected in case of protein breakdown (Colinet et al. 2007; Colinet et al. 2012; Koštál et al. 2011; Lalouette et al. 2007; Malmendal et al. 2006). 
In contrast, total FAA concentration was the highest at low temperatures. Finally, it should be acknowledged that we could not measure the whole spectrum of FAA in this study due to the chromatographic procedure used (see ESM1). Large variations in the amounts of proline cannot be excluded, and changes in this abundant FAA could significantly alter the total FAA concentration. Nonetheless, protein breakdown remains unlikely at $20{ }^{\circ} \mathrm{C}$ given the uneven variations of other FAA. This contrasts with the hypothesis of FAA accumulation under stressful temperatures but, together with the $100 \%$ survival, it may alternatively suggest that $20^{\circ} \mathrm{C}$ represented only limited thermal stress.

Thermal tolerant invertebrates usually accumulate polyols in response to cold exposure, as these compatible solutes have a cryoprotective function and protect cell membranes and protein stability (Salvucci 2000; Yoder et al. 2006; Michaud et al. 2008). This likely explains the accumulated inositol and glycerol in $0{ }^{\circ} \mathrm{C}$-exposed individuals, which supports our second hypothesis of accumulation of compatible solutes at low temperatures. Although the natures of the cellular damages resulting from heat and cold may differ, there are similar physiological symptoms between the two types of thermal stress. Insects may have evolved similar responses, and there are for instance numerous reports of increased concentrations of polyols resulting from heat stress (Rujiter et al. 2003; Michaud et al. 2008; Rangel et al. 2008; Burke et al. 2009). The manifold accumulation of erythritol in $M$. soledadinus exposed to $20{ }^{\circ} \mathrm{C}$ did not result in significance of the test on total polyols, likely due to very low concentration relative to other polyols. The change in its concentration in warm-exposed individuals is still worth note given that all other groups of individuals clustered together, and this peculiar physiological response after prolonged exposure at $20{ }^{\circ} \mathrm{C}$ may indicate thermal stress. Accumulation of this polyol has already been observed in heat-treated insects (Burke et al. 2009), but contrasts with the report by Michaud et al. (2008) that erythritol was not accumulated following heat stress in a polar midge (Belgica antarctica Jacobs; Dip., Chironomidae). Interestingly though, these authors found higher amounts of erythritol associated with desiccation and suggested a protective function against this stressor. Desiccation may be closely related to heat exposure due to decreasing relative humidity when temperature increases, and $M$. soledadinus is known as sensitive to desiccation (Todd and Block 1997). The very low erythritol concentration measured in the present study is unlikely to yield effective protection against body water loss. However, its manifold variation may indicate first signs of desiccation at $20^{\circ} \mathrm{C}$, rather than detrimental consequences of temperature per se.

When fed, warm-exposed beetles also differed from all others by their increased amounts of cadaverine, consistent with our first hypothesis of polyamine accumulation at stressful temperatures. Such accumulation has already been shown in insects under thermal tress (Michaud et al. 2008) and has been reported as a signal inducing expression of Heat Shock Proteins (HSP) in plants (Gill and Tuteja 2010). Supportive of this idea, the expression of stress genes associated with HSP depends on thermal acclimation in fruit flies (Colinet and Hoffmann 2012). Meanwhile, a two-week exposure to $20{ }^{\circ} \mathrm{C}$ did not significantly alter the expression of mRNA HSC70 in M. soledadinus compared to cooler treatments, regardless of trophic status (Siaussat et al. 2013). 
This suggested that such conditions were not at a level that caused thermal stress for this species. The association between HSP and food deprivation has been reported in a number of organisms but remains unclear in insects due to contrasting results (see Siaussat et al. 2013). Cadaverine has also been demonstrated as an efficient stabilizer of the DNA structure in stressed organisms by binding onto the DNA double helix (Petraccone et al. 2004). Alternatively, while food-deprived individuals may have spared reserves, the metabolic rate of fed beetles may have been elicited at $20^{\circ} \mathrm{C}$ as a result of the non-linear temperature-performance relationship in insects, ultimately increasing the production of reactive oxygen species (ROS) against which cadaverine has been proven as an efficient metabolite (Rhee et al. 2007).

Finally, gluconolactone was comparatively abundant in all individuals but consistently decreased with warming. This compound may originate from gluconolactone-6-phosphate produced by the pentose phosphate pathway (Hidalgo et al. 2013), which is usually stimulated under adverse conditions as it yields compatible solutes (Storey and Storey 1991; Koštál et al. 2004) and NADPH, a reductant source (Kruger and von Schaewen 2003). The continuous decrease in gluconolactone might thus highlight the adaptive component of the physiological plasticity of $M$. soledadinus to thermal variations. Nonetheless, caution must be taken with this hypothesis because gluconolactone can also act as an energy source through its conversion into glucose, which can in turn fuel the TCA cycle with pyruvate production resulting from glycolysis.

\subsection{The observed metabolic response to increasing temperature suggests increasing activity}

As hypothesized, gradual adjustments pertaining to increasing metabolic rate have been observed with increasing temperature. This effect is expected in ectotherms as a passive result of enzymatic kinetics being altered by temperature (Huey and Kingsolver 1989). Energy production is also expected to be modulated by changes in mitochondrial number depending on thermal acclimation (Lefebvre and Fourche 1985; Joanisse and Storey 1995; McMullen and Storey 2008). Consistent with these expectations, energy reserves such as carbohydrates (glucose, and most of all trehalose) decreased with increasing temperature. Trehalose is also known as a multifunctional molecule being accumulated under a range of adverse conditions such as heat, cold, oxidation or desiccation to protect proteins and cellular membranes (Elbein et al. 2003), but the gradual decrease over a range of temperatures covering the preferendum rather suggests its use as a source of energy.

The continuously decreasing fumarate with increasing temperature plus the decreased levels of succinate at temperatures above $0{ }^{\circ} \mathrm{C}$ support changes in the kinetics of the TCA cycle. Interpreting concentrations of individual IAM is particularly challenging because of their temporary nature in metabolic cycles: the apparent accumulation of any IAM in a metabolomics snapshot may indicate either acceleration or slowdown of the TCA cycle. However, increasing temperature within the thermal range considered here is known to increase both locomotor activity (Ottesen 1990) and oxygen consumption (Todd 1997; Lalouette et al. 2012) in M. soledadinus, thereby supporting elicited TCA cycle. 
The resulting increased energetic metabolism is likely partly responsible for the aforementioned diminution of some carbohydrates.

Finally, several FAA were found to decrease over the thermal range we studied. Glutamate, glycine, leucine, phenylalanine, serine and threonine showed the clearest decreasing patterns (not all were statistically analyzed due to strong correlations). Of note, glutamate, glycine and serine directly or indirectly contribute to the TCA cycle as precursors of aketoglutarate, choline, and acetate, respectively. Altogether, the results from the physiological scale are consistent with previous findings suggesting that such temperature gradient lies in the physiological range of this species (Lalouette et al. 2012). We also confirmed that $0{ }^{\circ} \mathrm{C}$ is suboptimal in this species due to the resulting inhibition of metabolic rate and expected stand-by of some biological functions; the metabolic rate kinetics increased starting from $4{ }^{\circ} \mathrm{C}$ onwards.

In accordance with the assumption of lowered sensitivity to global warming at high latitudes (Deutsch et al. 2008), this invader from austral origin appears to have significant scope to withstand ongoing warming at the sub-Antarctic islands, as it thermal limits are unlikely to be reached in this region. Moreover, rising air temperature may assist its altitudinal progression and invasion dynamics by increasing habitat suitability (harsh climate is assumed as the main factor currently limiting the colonization of high elevation habitats), growth rate, and temporal window of activity, rather than inhibit them. Nonetheless, climate change at the Kerguelen Islands also induces a dramatic reduction of rainfalls (approximately a twofold reduction since the 1960s; Lebouvier et al. 2011), which might increasingly impact M. soledadinus' range in the future in case of desiccation stress in its habitats.

\subsection{Invasion risks: the relevance of $\mathrm{M}$. soledadinus' thermal tolerance}

The expected increased biological activity of $M$. soledadinus triggers a warning for South Georgia, where the species has also been accidentally introduced (first record in 1963; Darlington 1970). The extent of its invasion in South Georgia remains limited compared to the Kerguelen Islands, with much smaller populations (Convey et al. 2011; Lebouvier et al. 2011). Most likely reasons for this lower invasive success are (i) the presence of Trechisibus antarcticus Dejean (Col., Carabidae), another invasive predaceous ground beetle whereas $M$. soledadinus suffers no competition in the Kerguelen Islands, and (ii) harsher climate (Convey et al. 2011; Lebouvier et al. 2011). It has been hypothesized that greater invasive success of $T$. antarcticus is due to its higher metabolic rate and better cold adaptation (Todd 1997). Consequently, if harsh thermal conditions of South Georgia tend to warm up in the future, beneficial effects on $M$. soledadinus' invasive success may be twofold: its capability to colonize a wider range of terrestrial habitats may increase, while the competitive advantage of $T$. antarcticus may progressively fade. 
Overall, the physiological tolerance of $M$. soledadinus to warm temperatures and limited signs of stress even without food, as well as its survival to prolonged starvation (Laparie et al. 2012a), emphasize the importance of reevaluating contamination risk within the sub-Antarctic region. In addition, thermal tolerance to constant regimes tend to underestimate survival and plasticity under fluctuating regimes that are the most likely in nature, as they allow periodic returns to optimal or sub-optimal conditions. The present results show that adults may withstand transportation inside ship cabins (provided that humidity is high enough), while the dense populations of this insect at the Port-aux-Français research station may increase the likeliness of unintentional sampling. Gravid females may passively travel towards other subAntarctic regions if picked up in invaded areas with supplies, clothing, mountain backpacks, or any gear being transported inside ship cabins and rooms where biosecurity policies are the least stringent.

Frenot et al. (2005) reemphasized importance of adequate biosecurity measures to limit the transportation of aliens to and among French sub-Antarctic islands. Current policies focus on (i) preventing transportation of outdoor materials among all visited archipelagos (containers and huts are specific to archipelagos), and (ii) protecting the Crozet archipelago from aliens from the Kerguelen Islands because of similar temperatures (the scientific ship in the area avoids moving back to Crozet after a stop at the Kerguelen Islands). Our results suggest that archipelagos warmer than Crozet, like Amsterdam \& St Paul, might also be suitable for this beetle, temperature-wise. These stringent measures apply to ships used to resupply the sub-Antarctic stations but are difficult to extend to military and fisheries ships that commonly refuel at the stations; emergencies or oceanographic campaigns may also occasionally enable moves of supply ships from the Kerguelen Islands to Crozet. The volumes of traded outdoor materials (likely the main vector of invertebrates) remain low in the above exceptions. However, people and the equipment they store in cabins are potential vectors of $M$. soledadinus that have mostly been overlooked. While Chown et al. (2012) recently demonstrated the importance of such vector pathways for resistance form propagules, awareness of visitors of the Kerguelen Islands should now be improved as active hitchhikers of the most problematic invasive insect locally might just share their cabin and sit in their backpack.

\section{Acknowledgements}

This research was supported by the Institut Polaire Francais (IPEV, programme 136), the CNRS (Zone-Atelier de Recherches sur l'Environnement Antarctique et Subantarctique), and the Agence Nationale de la Recherche (ANR-07VULN-004, Vulnerability of native communities to invasive insects and climate change in sub-Antarctic Islands, EVINCE). The authors thank INEE-CNRS for the funding of the 'ALIENS' application (ENVIROMICS call 2014). 


\section{References}

Burke G, Fiehn O, Moran N (2009) Effects of facultative symbionts and heat stress on the metabolome of pea aphids. ISME J 4:242-252. doi: 10.1038/ismej.2009.114

Cassey P, Blackburn T, Duncan R, Chown S (2005) Concerning invasive species: reply to Brown and Sax. Austral Ecol 30:475-480. doi: 10.1111/j.1442-9993.2005.01505.x

Chevrier M (1996) Introduction de deux espèces d'insectes aux lles Kerguelen: processus de colonisation et exemples d'interactions. Thèse de Doctorat d'Université, Université de Rennes 1

Chown SL, Gremmen NJM, Gaston KJ (1998) Ecological biogeography of Southern Ocean Islands: species-area relationships, human impacts, and conservation. Am Nat 152:562-575

Chown SL, Hoffmann AA, Kristensen TN, Angiletta MJ, Stenseth NC, Pertoldi C (2010) Adapting to climate change: a perspective from evolutionary physiology. Clim Res 43:3-15

Chown SL, Huiskes AHL, Gremmen NJM, Lee JE, Terauds A, Crosbie K, Frenot Y, Hughes KA, Imura S, Kiefer K, Lebouvier M, Raymond B, Tsujimoto M, Ware C, Van de Vijver B, Begstrom DM (2012) Continent-wide risk assessment for the establishment of nonindigenous species in Antarctica? P Natl Acad Sci USA 109: 4938-4943. doi: 10.1073/pnas.1119787109

Chown SL, Smith VR (1993) Climate change and the short-term impact of feral house mice at the sub-Antarctic Prince Edward Islands. Oecologia 96:508-516. doi: 10.1007/BF00320508

Colinet H., Hance T., Vernon P., Bouchereau A., Renault D. (2007) Does fluctuating thermal regime trigger free amino acid production in the parasitic wasp Aphidius colemani (Hymenoptera: Aphidiinae)? Comp Biochem Physiol A 147:484-492

Colinet, H, Hoffmann AA (2012) Comparing phenotypic effects and molecular correlates of developmental, gradual and rapid cold acclimation responses in Drosophila melanogaster. Funct Ecol 26:84-93

Colinet H, Larvor V, Laparie M, Renault D (2012) Exploring the plastic response to cold acclimation through metabolomics. Funct Ecol 26:711-722. doi: 10.1111/j.1365-2435.2012.01985.x

Convey P, Key RS, Key RJD, Belchier M, Waller CL (2011) Recent range expansions in non-native predatory beetles on sub-Antarctic South Georgia. Polar Biol 34:597-602. doi: 10.1007/s00300-010-0909-6

Deutsch CA, Tewksbury JJ, Huey RB, Sheldon KS, Ghalambor CK, Haak DC, Martin PR (2008) Impacts of climate warming on terrestrial ectotherms across latitude. P Natl Acad Sci USA 105:6668-6672

Elbein AD, Pan YT, Pastuszak I, Carroll D (2013) New insights on trehalose: a multifunctional molecule. Glycobiology 13:17R-27R

Fiehn O, Wohlgemuth G, Scholz M, Kind T, Lee DY, Lu Y, Moon S, Nikolau B (2008) Quality control for plant metabolomics: reporting MSI-compliant studies. Plant J 53:691-704

Frenot Y, Chown SL, Whinam J, Selkirk PM, Convey P, Skotnicki M, Bergstrom DM (2005) Biological invasions in the Antarctic: extent, impacts and implications. Biol Rev 80:45-72.

Frenot Y, Gloaguen JC, Massé L, Lebouvier M (2001) Human activities, ecosystem disturbance and plant invasions in subantarctic Crozet, Kerguelen and Amsterdam Islands. Biol Conserv 101:33-50. doi: 16/S0006-3207(01)00052-0

Gill SS, Tuteja N (2010) Polyamines and abiotic stress tolerance in plants. Plant Signal and Behav 5:26-33

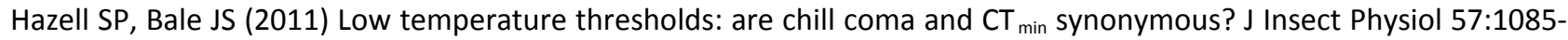
1089

Hidalgo K, Laparie M, Bical R, Larvor V, Bouchereau A, Siaussat D, Renault D (2013) Metabolic fingerprinting to salinity in the invasive ground Merizodus soledadinus at the Kerguelen Islands: does physiological plasticity and ecological range match? J Insect Physiol 59:91-100.

Huey RB, Kingsolver JG (1989) Evolution of thermal sensitivity of ectotherm performance. Trends Ecol Evol 4:131135

Hulme PE, Bacher S, Kenis M, Klotz S, Kühn I, Minchin D, Nentwig W, Olenin S, Panov V, Pergl J, Pyšek P, Roques A, Sol $D$, Solarz W, Vilà M (2008) Grasping at the routes of biological invasions: a framework for integrating pathways into policy. J Appl Ecol 45:403-414. doi: 10.1111/j.1365-2664.2007.01442.x

Jeannel R (1940) Croisière du Bougainville aux îles australes françaises. III. Coléoptères. Memoires du Muséum National d'Histoire Naturelle, France, Série A 14:63-202 
Joanisse DR, Storey KB (1995) Temperature-acclimation and seasonal responses by enzymes in cold-hardy gall insects. Arch Insect Biochem Physiol 28:339-349

Johns PM (1974) Arthropoda of the subantarctic islands of New Zealand. I. Coleoptera: Carabidae. Southern New Zealand, Patagonian and Falkland Islands insular Carabidae. J R Soc N Z 4:283-302

Khodayari S, Moharramipour S, Larvor V, Hidalgo K, Renault D (2013) Metabolic changes associated with coldhardiness in the two-Spotted spider mite: effect of acclimation and diapause. PLoS ONE 8(1), e54025.

Koštál V, Vambera J, Bastl J (2004) On the nature of pre-freeze mortality in insects: water balance, ion homeostasis and energy charge in the adults of Pyrrhocoris apterus. J Exp Biol 207:1509-1521

Koštál V, Renault D, Rozsypal J (2011) Seasonal changes of free amino acids and thermal hysteresis in overwintering heteropteran insect, Pyrrhocoris apterus. Comp Biochem Physiol A 160:245-251

Kruger NJ, von Schaewen A (2003) The oxidative pentose phosphate pathway; structure and organization. Curr Opin Plant Biol 6:236-246

Lalouette L, Kostal V, Colinet H, Gagneul D, Renault D (2007) Cold exposure and associated metabolic changes in adult tropical beetles exposed to fluctuating thermal regimes. FEBS J 274:1759-1767. doi: doi:10.1111/j.17424658.2007.05723.x

Lalouette L, Williams CM, Cottin M, Sinclair BJ, Renault D (2012) Thermal biology of the alien ground beetle Merizodus soledadinus introduced to the Kerguelen Islands. Polar Biol 35:509-517. doi: 10.1007/s00300-011-1096-9

Laparie M, Larvor V, Frenot Y, Renault D (2012a) Starvation resistance and effects of diet on energy reserves in a predatory ground beetle (Merizodus soledadinus; Carabidae) invading the Kerguelen Islands. Comp Biochem Physiol A 161:122-129. doi: 10.1016/j.cbpa.2011.09.011

Laparie M, Bical R, Larvor V, Vernon P, Frenot Y, Renault D (2012b) Habitat phenotyping of two sub-Antarctic flies by metabolic fingerprinting: evidence for a species outside its home? Comp Biochem Physiol A 162:406-412.

Lebouvier M, Laparie M, Hullé M, Marais A, Cozic Y, Lalouette L, Vernon P, Candresse T, Frenot Y, Renault D (2011) The significance of the sub-Antarctic Kerguelen Islands for the assessment of the vulnerability of native communities to climate change, alien insect invasions and plant viruses. Biol Invasions 13:1195-1208.

Lefebvre F, Fourche J (1985) Mitochondrial aspects of cold acclimation in Pieris brassicae (Lepidoptera) during diapause and post-diapause imaginal development. J Therm Biol 10:29-33

Lombaert E, Guillemaud T, Cornuet JM, Malausa T, Facon B, Estoup A (2010) Bridgehead effect in the worldwide invasion of the biocontrol Harlequin Ladybird. PLOS ONE 5(3), e9743.

Malmendal A, Overgaard J, Bundy JG, Sørensen JG, Nielsen NC, Loeschcke V, Holmstrup M (2006) Metabolomic profiling of heat stress: hardening and recovery of homeostasis in Drosophila. Am J Physiol-Reg I 291:R205-R212

Mamai W, Mouline K, Blais C, Larvor V, Dabiré KR, Ouedraogo A, Simard F, Renault D (2014) Metabolomic and ecdysteroid variations in Anopheles gambiae s.l. mosquitoes exposed to the stressful conditions of the dry season in Burkina Faso, West Africa. Physiol Biochem Zool 87:486-497

McMullen DC, Storey KB (2008) Mitochondria of cold hardy insects: responses to cold and hypoxia assessed at enzymatic, mRNA and DNA levels. Insect Biochem Molec 38:367-373

Michaud MR, Benoit JB, Lopez-Martinez G, Elnitsky MA, Lee REJ, Denlinger DL (2008) Metabolomics reveals unique and shared metabolic changes in response to heat shock, freezing and desiccation in the Antarctic midge, Belgica antarctica. J Insect Physiol 54:645-655

Ottesen PS (1990) Diel activity patterns of Carabidae, Staphylinidae and Perimylopidae (Coleoptera) at South Georgia, Sub-Antarctic. Polar Biol 10:515-519. doi: 10.1007/BF00233700

Overgaard J, Malmendal A, Sørensen JG, Bundy JG, Loeschcke V, Nielsen NC, Holmstrup M (2007) Metabolomic profiling of rapid cold hardening and cold shock in Drosophila melanogaster. J Insect Physiol 53:1218-1232

Petraccone L, Baiano S, Fiorentino G, Barone G, Giancola C (2004) Simultaneous effect of cadaverine and osmolytes on ct-DNA thermal stability. Thermochim Acta 418:47-52

R Development Core Team (2008) R: A Language and Environment for Statistical Computing. 1:ISBN 3-900051-07-0

Rangel DE, Anderson AJ, Roberts DW (2008) Evaluating physical and nutritional stress during mycelial growth as inducers of tolerance to heat and UV-B radiation in Metarhizium anisopliae conidia. Mycol Res 112:1362-1372.

Ruijter GJ, Bax M, Patel H, Flitter SJ, van de Vondervoort PJ, de Vries RP, vanKuyk PA, Visser J (2003) Mannitol is required for stress tolerance in Aspergillus niger conidiospores. Eukaryot Cell 2:690-698 
Rhee HJ, Kim EJ, Lee JK (2007) Physiological polyamines: simple primordial stress molecules. J Cell Mol Med 11:685703

Roig-Junent S, Dominguez MC (2001) Diversidad de la familia Carabidae (Coleoptera) en Chile. Revista Chilena de Historia Natural 74:549-571

Salvucci ME (2000) Sorbitol accumulation in whiteflies: evidence for a role in protecting proteins during heat stress. J Therm Biol 25:353-361

Siaussat D, Laparie M, Maria A, Renault D (2013) Heat shock protein responses to salinity, food deprivation, and temperature in the invasive ground beetle Merizodus soledadinus at the Kerguelen Islands. Polar Biol 36:201-209

Simberloff D (2011) How common are invasion-induced ecosystem impacts? Biol Invasions 13:1255-1268. doi: 10.1007/s10530-011-9956-3

Storey JM, Storey KB (2005) Cold hardiness and freeze tolerance. In: Storey KB (ed) Functional metabolism: regulation and adaption. John Wiley \& Sons Inc, Hoboken, pp. 473-503

Todd CM (1997) Respiratory metabolism in two species of carabid beetle from the sub-Antarctic island of South Georgia. Polar Biol 18:66-171

Todd CM, Block W (1997) Responses to desiccation in four coleopterans from sub-Antarctic South Georgia. J Insect Physiol 43:905-913

Vitousek PM, Mooney HA, Lubchenco J, Melillo JM (1997) Human domination of Earth's ecosystems. Science 277:494499

Yoder JA, Benoit JB, Denlinger DL, Rivers DB (2006) Stress-induced accumulation of glycerol in the flesh fly, Sarcophaga bullata: evidence indicating anti-desiccant and cryoprotectant functions of this polyol and a role for the brain in coordinating the response. J Insect Physiol 52:202-214

Waller M, Whitney R, Taylor M, Miyagawa H, Matsuda K, Nakagawa K (2007) Multiresidue pesticides analysis using synchronous scan/SIM mode GC-MS. LC GC N Am 25:39 